\title{
Regulating Vegetative Growth and Flowering with Gibberellic Acid in Intact Plants and Cultured Phylloclades of 'Crimson Giant' Easter Cactus
}

\author{
Thomas H. Boyle', Michael Marcotrigiano', and Suzanne M. Hamlin² \\ Department of Plant and Soil Sciences, French Hall, University of Massachusetts, Amherst, MA 01003 \\ Additional index words. flowering potted plant, $\mathrm{GA}_{3}$, Hatiora gaertneri, ornamental plant, Rhipsalidopsis gaertneri \\ Abstract. Investigations were performed to determine the influence of gibberellic acid $\left(\mathrm{GA}_{3}\right)$ on intact plants and cultured \\ phylloclades of 'Crimson Giant' Easter cactus [Rhipsalidopsis gaertneri (Regel) Moran]. Responses of intact plants \\ depended on $\mathbf{G A}_{3}$ concentration, number of spray applications, and application time. Single $\mathbf{G A}_{3}$ applications delayed \\ flowering and reduced the percentage of apical phylloclades flowering and number of flower buds per plant when applied \\ before floral primordia formation [from 20 days before to the start of long days (LDs)], but hastened flowering and did \\ not affect the percentage of apical phylloclades flowering or number of flower buds per plant when applied during floral \\ bud development ( 20 days after the start of LDs). When sprays were applied at or before the start of LDs, increasing the \\ GA, concentration resulted in fewer plants flowering, longer flowering delays, and further decreases in the number of \\ flower buds per plant. Multiple GA $_{3}$ applications were more inhibitory to flowering than single applications. Whole plants \\ and cultured phylloclades exhibited similar reactions to $\mathbf{G A}_{3}$, but cultured phylloclades were more responsive to $\mathbf{G A}_{3}$ than \\ intact plants. Intact plants and cultured phylloclades generally produced more new phylloclades as $\mathbf{G A}_{3}$ concentration \\ increased. Spine growth also increased when phylloclades were cultured in a $\mathbf{G A}_{3}$-containing medium. Flowering was \\ accelerated by $\approx \$ 5$ days when GA, was applied to intact plants with 1- to 2 -mm-long flower buds. GA, may be horticulturally \\ useful for Easter cactus crop scheduling.
}

Easter cactus-currently Rhipsalidopsis gaertneri (Regel) Moran (Liberty Hyde Bailey Hortorium, 1976), but proposed by Barthlott (1987) as Hatiora gaertneri (Regel) Barthlott-is an epiphytic shrub with a determinate growth pattern that produces a series of flattened, two-ribbed joints (phylloclades). Areoles (modified axillary buds) are restricted to the margins and apexes of phylloclades (Liberty Hyde Bailey Hortorium, 1976). Areoles that develop below the phylloclade apex are solitary, whereas, at the apex, areoles are crowded together to form a composite areole (Barthlott, 1987). Flowers and new phylloclades develop almost invariably from composite areoles on apical phylloclades and infrequently from subapical areoles or subapical phylloclades (Boyle, 1992; Liberty Hyde Bailey Hortorium, 1976).

Areoles area prominent anatomical feature of cacti, and each areole contains several spine primordia and an areolar meristem (Boke, 1944). Vegetative shoots (phylloclades), leaves, spines, flowers, and roots arise through the activity of the areolar meristem (Gibson and Nobel, 1986). Mauseth and Halperin (1975) were able to regulate the developmental pattern in cultured areoles of Opuntia polyacantha Haw. by varying the proportions of $\mathrm{GA}_{3}$, cytokinin, and auxin in the medium. These results demonstrate that exogenously applied $\mathrm{GA}_{3}$ may strongly influence the developmental fate of the areolar meristem.

Exogenously applied GA has modified growth and development in a wide range of plants. Growth of stems and other organs is promoted by GA and results from enhanced cell division, increased carbohydrate hydrolysis, and increased cell-wall plasticity (Sachs, 1961; Salisbury and Ross, 1978). GA also regulates or promotes flowering in several species. GA induces many long-

Received for publication 30 Dec. 1992. Accepted for publication 11 May 1993. Publication no. 3086 of the Massachusetts Agricultural Experiment Station. The cost of publishing this paper was defrayed in part by the payment of page charges. Under postal regulations, this paper therefore must be hereby marked advertisement solely to indicate this fact.

${ }^{1}$ Associate professor.

${ }^{2}$ Undergraduate student. day (LD) plants to flower under noninductive short days (SDS) (Lang and Reinhard, 1961; Wittwer and Bukovac, 1958) and substitutes for the LD phase in several dual-photoperiod species, including long-short-day plants (LSDPs) (Bünsow and Harder, 1956) and short-long-day plants (SLDPs) (Chouard, 1960; Ketellapper and Barbaro, 1966). In short-day plants (SDPs), GA applied during inductive photoperiods generally inhibits or delays floral initiation (Vince-Prue, 1975), but GA may accelerate floral development if applied after floral initiation (Greulach and Haesloop, 1958; Stuart and Cathey, 1962). In the SDP Schlumbergera truncata (Haw.) Moran (Cactaceae), GA inhibits flower bud formation and delays flowering when applied before or at the beginning of SDS, accelerates flowering by up to 2 weeks when applied at the visible bud stage (buds 1 to $3 \mathrm{~mm}$ long), and has no or little influence when applied in the late flower development stage (buds 6 to $8 \mathrm{~mm}$ long) (Fujihara, 1959; Halevy and Rudich, 1968; Ho et al., 1985; Runger, 1984). In a few SDPs, GA has promoted floral initiation when applied to plants under noninductive LDs (Nanda et al., 1967; Wittwer and Bukovac, 1958), but GA cannot substitute for the SD requirement in most SDPs. Further, $\mathrm{GA}_{3}$ cannot replace the $\mathrm{SD}$ phase in several dual-photoperiod species (Ketellapper and Barbaro, 1966; Penner, 1960; Wellensiek, 1960).

Limited information has been published on the responses of $R$. gaertneri to growth regulators (Boyle, 1992; Boyle et al., 1988; Kaukovirta, 1979), and we are unaware of any published reports on the responses of $R$. gaertneri to $\mathrm{GA}_{3}$. The purpose of this research was to determine the morphological responses of intact plants and cultured phylloclades of the SLDP $R$. gaertneri 'Crimson Giant' to application time, number of applications, and concentration of exogenously applied $\mathrm{GA}_{3}$.

\section{Materials and Methods}

General procedures. Plants were propagated and grown in glasshouses at the Univ. of Massachusetts, Amherst (lat. $42^{\circ} 22.5^{\prime} \mathrm{N}$ ). 
Plants were fertilized weekly with $20 \mathrm{~N}-4.3 \mathrm{P}-16.6 \mathrm{~K}\left(12 \% \mathrm{NO}_{3}-\mathrm{N}\right.$, $\left.8 \% \mathrm{NH}_{4}-\mathrm{N}\right)$ at $200 \mathrm{mg} \mathrm{N} /$ liter. Fertilization began after phylloclades were rooted and was discontinued 4 weeks before the start of LDs to hasten apical phylloclade maturation. Four weeks after start of LDs, fertilization was resumed and applied at $200 \mathrm{mg} / \mathrm{N}$ per liter every 2 weeks until the experiments ended

Thermostat setpoints were $18 / 20 \mathrm{C}$ (heat-vent) during all experiments. Photosynthetic photon flux (PPF) and air temperatures were monitored with a datalogger (model LI- 1000) equipped with a quantum sensor (model LI- 190SA) and an aspirated thermistor (model LI-1OOO- 16; LI-COR, Lincoln, Neb.). The datalogger was configured with a sampling interval of $60 \mathrm{sec}$ and recorded mean PPFs and temperatures at $1-\mathrm{h}$ intervals. $\mathrm{GA}_{3}$ was applied to intact plants (Expts. 1 and 2) near midday (1200 HR); temperature, PPF, and natural photoperiod on $\mathrm{GA}_{3}$ application dates are provided in Table 1.

Multiple $\mathrm{GA}_{3}$ applications on intact plants (Expt. 1). Whole phylloclades were propagated on 28 Apr. 1987 in 72-cell plastic trays using one phylloclade per $35-\mathrm{cm}^{3}$ cell. The propagation medium was a commercial soilless mix composed of sphagnum peat, perlite, and vermiculite (Fafard Mix no. 2, Conrad Fafard, Springfield, Mass.). Rooted phylloclades were transplanted singly into $520-\mathrm{cm}^{3}$ ( $10-\mathrm{cm}$-diameter) plastic pots containing Fafard Mix no. 2. Plants received natural daylengths (NDs) from propagation until 10 Jan. 1988. LDs were provided from 10 Jan. until the experiment ended by supplementing ND with incandescent irradiation at $3 \mu \mathrm{mol} \cdot \mathrm{m}^{-2} \cdot \mathrm{s}^{-1}$ (400 to $700 \mathrm{~nm}$ ) from 1600 to $2200 \mathrm{HR}$. Actual glasshouse temperatures were $18 \pm 1.5 \mathrm{C}$ nights $/ 20 \pm 2 \mathrm{C}$ days and ranged from 16 to $26 \mathrm{C}$.

Treatments included an unsprayed control and $\mathrm{GA}_{3}$ (Pro-Gibb; Abbott Labs, North Chicago) at 25 or $50 \mathrm{mg} \cdot \mathrm{liter}^{-1}$ in one, two, three, or four applications. $\mathrm{GA}_{3}$ solutions contained Tween 20 (polyoxyethylene sorbitan monolaurate) at $1 \mathrm{ml} \cdot \mathrm{liter}^{-1}$ as a surfactant and were applied to plants with a hand sprayer at $\approx 15 \mathrm{ml} / \mathrm{plant}$. The initial treatment was applied on 10 Jan.; the other abdication dates were 17, 24, and 31 Jan. The experiment was a completely randomized design with eight pots per treatment.

Data were collected on days to flowering from the start of LDs (10 Jan.) to full expansion of the first flower, number of flower buds per flowering apical phylloclade, number of flower buds per plant, and percentage of apical phylloclades flowering. The experiment ended on $20 \mathrm{Apr}$. 1988. Before statistical analysis, the numbers of flower buds per flowering apical phylloclade and new apical phylloclades per plant were $\log$-transformed $\left[\log _{10}(X+1)\right]$ and percentage values were arcsin-transformed. All variables were analyzed by SAS's (1985) General Linear Model (GLM) procedure. Single degree-of-freedom contrasts were used to test for treatment differences.

Single $\mathrm{GA}_{3}$ applications on intact plants (Expt. 2). Whole phylloclades were propagated on 27 Mar. 1988 using procedures and materials described in Expt. 1. Rooted phylloclades were transplanted singly into $520-\mathrm{cm}^{3}$ plastic pots containing Fafard Mix no. 2. Plants were grown under ND from propagation until 31 Jan. 1989, and were then given LDs (as described in Expt. 1) until the experiment ended. Actual glasshouse temperatures were $18 \pm$ $1.5 \mathrm{C}$ nights $/ 21 \pm 2 \mathrm{C}$ days and ranged from 16 to $28 \mathrm{C}$. Treatments included $\mathrm{GA}_{3}$ (Pro-Gibb) at 5,50, and $500 \mathrm{mg} \cdot \mathrm{liter}^{-1}$ and an unsprayed

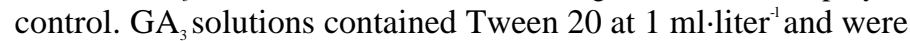
applied with a hand sprayer at $\approx 15 \mathrm{ml} /$ plant. Treatments were applied on 11 Jan. (20 days before the start of LDs), 21 Jan. (10 days before the start of LDs), 31 Jan. (start of LDs), 10 Feb. (10 days after start of LDs), and 20 Feb. (20 days after the start of LDs). The experiment was a completely randomized design with eight pots per treatment.

At the start of LDs, 24 mature apical phylloclades were removed from eight supplementary plants (three phylloclades per plant) that were the same age and maintained under the same conditions as the controls. Apexes were dissected under a stereomicroscope at $\times 50$ magnification to determine the developmental stage of the areolar meristems in the composite areole. Data were also collected on the presence of visible flower buds at each application date, flower bud length, days to flowering from the start of LDs (31 Jan.) to full expansion of the first flower, number of flower buds per plant, number of new apical phylloclades per plant, percentage of apical phylloclades flowering, and percentage of apical phylloclades with new phylloclades. The experiment ended on 1 May 1989. Chi-square tests were used to test for differences in percentage of flowering plants between $\mathrm{GA}_{3}$ treatments and controls. Other variables were analyzed by SAS's ( 1985) GLM procedure. Percentage variables were arcsin-transformed and numbers of flower buds and new apical phylloclades per plant were log-transformed before analysis. Single degree-of-freedom contrasts were used to test for treatment differences.

In vitro responses of phylloclades cultured on $G_{3}$-containing media (Expt. 3). Mature apical phylloclades were harvested on 21 Feb. 1990 from glasshouse-grown stock plants. Before harvest, stock plants were exposed to 8 weeks of 8-h SDs (0800 to $1600 \mathrm{HR}$ ) to satisfy the SD phase for flowering (Boyle, 1991). Surface contamination was reduced by pruning the bristly spines on the composite areole with scissors. Phylloclades were surface-disinfected by im-

Table 1. Glasshouse environmental conditions recorded on $\mathrm{GA}_{3}$ application dates.

\begin{tabular}{|c|c|c|c|c|c|}
\hline \multirow[b]{2}{*}{ Experiment } & \multirow{2}{*}{$\begin{array}{c}\mathrm{GA}_{3} \\
\text { application } \\
\text { date }\end{array}$} & \multirow{2}{*}{$\begin{array}{c}\text { Air } \\
\text { temp } \\
(\mathrm{C})^{\mathrm{z}}\end{array}$} & \multirow{2}{*}{$\begin{array}{l}\text { Photosynthetic } \\
\text { photon flux } \\
\left(\mu \mathrm{mol} \cdot \mathrm{m}^{-2} \cdot \mathrm{s}^{-1}\right)^{z}\end{array}$} & \multicolumn{2}{|c|}{$\begin{array}{c}\text { Natural } \\
\text { photoperiod }\end{array}$} \\
\hline & & & & $\mathrm{h}$ & $\overline{\min }$ \\
\hline \multirow[t]{4}{*}{$\overline{1}$} & 10 Jan. 1988 & $21.5 \pm 0.1$ & $442 \pm 44$ & 9 & 20 \\
\hline & 17 Jan. 1988 & $20.1 \pm 0.1$ & $389 \pm 24$ & 9 & 31 \\
\hline & 24 Jan. 1988 & $21.6 \pm 0.1$ & $136 \pm 26$ & 9 & 44 \\
\hline & 31 Jan. 1988 & $21.4 \pm 0.3$ & $607 \pm 66$ & 10 & 0 \\
\hline \multirow[t]{5}{*}{2} & 11 Jan. 1989 & $18.9 \pm 0.5$ & $153 \pm 20$ & 9 & 21 \\
\hline & 21 Jan. 1989 & $17.8 \pm 1.3$ & $422 \pm 107$ & 9 & 39 \\
\hline & 31 Jan. 1989 & $18.5 \pm 0.7$ & $259 \pm 30$ & 10 & 0 \\
\hline & 10 Feb. 1989 & $18.4 \pm 0.7$ & $373 \pm 79$ & 10 & 23 \\
\hline & 20 Feb. 1989 & $19.0 \pm 0.1$ & $292 \pm 71$ & 10 & 50 \\
\hline
\end{tabular}

$\overline{\bar{\pi}}$ Actual glasshouse air temperatures and photosynthetic photon flux were collected by a datalogger configured with a sampling interval of $60 \mathrm{sec}$ and recording mean values at 1-h intervals. Data are averages of hourly means ( \pm sE) for 1000 to 1359 HR. 'Duration of daylight (interval between sunrise and sunset) at lat. $42^{\circ} \mathrm{N}$. Data are from List (1951). 
mersing them for $25 \mathrm{~min}$ in a $20 \%$ (by volume) bleach solution $(1.05 \% \mathrm{NaOCl})$ containing $0.8 \%$ Tween 20 as a surfactant, followed by three rinses in sterile distilled water. Explants were obtained by excising $a \approx 1.5$-cm-long, wedge-shaped piece from the phylloclade apex, which included the entire composite areole. Explants were oriented vertically in $55-\mathrm{cm}^{3}(25-\mathrm{mm}$-diameter vials containing $10 \mathrm{ml}$ of sterile Murashige and Skoog (1962) medium that was solidified with $7 \mathrm{~g}$ Difco Bacto-agar/liter and supplemented with $\mathrm{GA}_{3}$ at $0,0.1,1,10$, or $100 \mathrm{mg} \cdot$ liter $^{-1}$. Crystalline $\mathrm{GA}_{3}$ (Grade III; Sigma, St. Louis) was dissolved in ethanol, and, to preserve $\mathrm{GA}_{3}$ activity, stock solutions were filter-sterilized and added after autoclaving the medium (van Bragt and Pierik, 1971). The experiment was a completely randomized design with 10 replications (vials) per treatment.

Cultures were maintained in a growth room maintained at $25 \pm$ $1.5 \mathrm{C}$. Irradiance was provided by cool-white fluorescent lamps $\left(\approx 35 \mu \mathrm{mol} \cdot \mathrm{m}^{-2} \cdot \mathrm{s}^{-1} \mathrm{PPF}\right)$, and a $16-\mathrm{h}$ (LD) photoperiod was maintained to induce flowering in the cultured phylloclades (Boyle, 199 1). After 35 days in vitro, data were collected on the numbers of flower buds and secondary $\left(2^{\circ}\right)$ phylloclades (those developing from the composite areole), and the presence of spine growth on the composite areole. The experiment was repeated on 12 Mar. 1990 using mature apical phylloclades collected from the stock plants previously described.

Percentage data were analyzed by single degree-of-freedom chi-square tests. Two variables (flower buds per explant and $2^{\circ}$ phylloclades per explant) were log-transformed and analyzed by SAS's (1985) GLM procedure using data combined from both experiments. Homogeneity of error variances was previously verified using a two-tailed F test (Gomez and Gomez, 1984).

\section{Results and Discussion}

Experiment 1. All plants produced flowers, regardless of $\mathrm{GA}_{3}$ concentration or number of applications. Compared to unsprayed plants, flowering was delayed and the percentage of apical phylloclades flowering and number of flower buds per plant was decreased in plants sprayed with $\mathrm{GA}_{3}$ (Table 2). Increasing the number of $\mathrm{GA}_{3}$ applications resulted in a linear increase in the number of days to flowering and linear decreases in the percentage of apical phylloclades flowering and number of flower buds per plant. With $\mathrm{GA}_{3}$ at $25 \mathrm{mg} \cdot \mathrm{liter}^{-1}$, the number of flower buds per flowering apical phylloclade was not affected by number of applications, but at $50 \mathrm{mg} \cdot \operatorname{liter}^{-1}$, the number of flower buds per flowering apical phylloclade decreased linearly as the number of applications increased. Generally, plants treated with $\mathrm{GA}_{3}$ at 50 mg.liter ${ }^{-1}$ produced fewer flowers and flowered later than plants treated with $25 \mathrm{mg} \cdot$ liter $^{-1}$.

Experiment 2. At the start of LDs, dome-shaped areolar meristems (150 to $175 \mu \mathrm{m}$ in diameter) and a few immature phylloclades $(<800 \mu \mathrm{m}$ long) were observed in the composite areoles of apical phylloclades collected from the supplementary plants. None of the composite areoles that were examined contained floral primordia. No flower buds were visible on plants when $\mathrm{GA}_{3}$ was applied from 20 days before to 10 days after start of LDs. At 20 days after start of LDs, flower buds were clearly visible on untreated plants and were a maximum of 1 to $2 \mathrm{~mm}$ long.

Flowering was either inhibited, unaffected, or accelerated by $\mathrm{GA}_{3}$, depending on concentration and application time (Table 3). Flowering was inhibited when $\mathrm{GA}_{3}$ at 50 or $500 \mathrm{mg} \cdot \mathrm{liter}^{-1}$ was applied at or before the start of LDs. Generally, one application of $\mathrm{GA}_{3}$ at $500 \mathrm{mg} \cdot \mathrm{liter}^{-1}$ resulted in fewer plants flowering, greater delays in flowering, and fewer flower buds compared to a single application of $\mathrm{GA}_{3}$ at $50 \mathrm{mg} \cdot$ liter ${ }^{-1}$. Applying $\mathrm{GA}_{3} 10$ days after the start of LDs did not affect days to flowering, but reduced the percentage of apical phylloclades flowering and number of flower buds per plant. When $\mathrm{GA}_{3}$ was applied 20 days after the start of LDs, flowering was hastened but the percentage of apical phyllo-

Table 2. Influence of $\mathrm{GA}_{3}$ concentration and number of applications on flowering of 'Crimson Giant' Easter cactus (Expt. 1).

\begin{tabular}{|c|c|c|c|c|c|}
\hline $\begin{array}{l}\mathrm{GA}_{3} \\
\text { concn } \\
\left(\mathrm{mg} \cdot \text { liter }^{-1}\right)\end{array}$ & $\begin{array}{c}\text { No. of } \\
\text { applications }\end{array}$ & $\begin{array}{c}\text { Days to } \\
\text { flowering }\end{array}$ & $\begin{array}{c}\text { Apical } \\
\text { phylloclades } \\
\text { flowering } \\
(\%)\end{array}$ & $\begin{array}{l}\text { Flower buds/ } \\
\text { flowering } \\
\text { apical } \\
\text { phylloclade } \\
\text { (no.) }\end{array}$ & $\begin{array}{c}\text { Flower buds/ } \\
\text { plant } \\
\text { (no.) }\end{array}$ \\
\hline 0 (control) & --- & 57 & 67 & 1.7 & 25.3 \\
\hline \multirow[t]{4}{*}{25} & 1 & 62 & 54 & 1.5 & 19.9 \\
\hline & 2 & 69 & 49 & 1.6 & 21.9 \\
\hline & 3 & 69 & 42 & 1.4 & 16.9 \\
\hline & 4 & 80 & 28 & 1.5 & 11.5 \\
\hline \multirow[t]{4}{*}{50} & 1 & 64 & 56 & 1.6 & 25.1 \\
\hline & 2 & 73 & 35 & 1.9 & 17.8 \\
\hline & 3 & 86 & 31 & 1.3 & 10.6 \\
\hline & 4 & 86 & 10 & 1.2 & 4.0 \\
\hline \multicolumn{6}{|l|}{ Contrasts } \\
\hline \multirow{2}{*}{\multicolumn{2}{|c|}{$\begin{array}{l}\text { Control vs. GA } \\
\text { Control vs. } 25 \mathrm{mg} \cdot \text { liter }^{-1}\end{array}$}} & $* * *$ & $* * *$ & NS & ** \\
\hline & & $* * *$ & $* * *$ & NS & $* *$ \\
\hline \multicolumn{2}{|c|}{ Control vs. $50 \mathrm{mg} \cdot$ liter $^{-1}$} & $* * *$ & $* * *$ & NS & $* *$ \\
\hline \multicolumn{2}{|c|}{$25 \mathrm{mg} \cdot$ liter $^{-1}$ vs. $50 \mathrm{mg} \cdot$ liter $^{-1}$} & $* * *$ & $* * *$ & NS & $* * *$ \\
\hline \multicolumn{2}{|c|}{$25 \mathrm{mg} \cdot \mathrm{liter}^{-1}$, no. applications linear } & $* *$ & $* * *$ & NS & $*$ \\
\hline \multicolumn{2}{|c|}{$25 \mathrm{mg} \cdot \operatorname{liter}^{-1}$, no. applications quadratic } & NS & NS & NS & NS \\
\hline \multicolumn{2}{|c|}{$50 \mathrm{mg} \cdot \mathrm{liter}^{-1}$, no. applications linear } & $* * *$ & $* * *$ & $*$ & $* * *$ \\
\hline \multicolumn{2}{|c|}{$50 \mathrm{mg} \cdot \operatorname{liter}^{-1}$, no. applications quadratic } & NS & NS & NS & NS \\
\hline
\end{tabular}

${ }^{\mathrm{z}}$ Days to flowering from start of long days (10 Jan. 1988) for all treatments.

Ns,,$* * * * * *$ Nonsignificant or significant at $0.05 \geq \alpha>0.01,0.01 \geq \alpha>0.001$, or $\alpha \leq 0.001$, respectively, according to $F$ test of contrast between treatments. 


\begin{tabular}{|c|c|c|c|c|c|c|c|}
\hline $\begin{array}{l}\mathrm{GA}_{3} \\
\text { concn } \\
\left(\mathrm{mg} \cdot \text { liter }^{-1}\right)\end{array}$ & $\begin{array}{l}\text { Application } \\
\text { time }^{z}\end{array}$ & $\begin{array}{c}\text { Plants } \\
\text { flowering } \\
(\%)\end{array}$ & $\begin{array}{l}\text { Days to } \\
\text { flowering }\end{array}$ & $\begin{array}{c}\text { Apical } \\
\text { phylloclades } \\
\text { flowering } \\
(\%)\end{array}$ & $\begin{array}{l}\text { Flower buds/ } \\
\text { plant } \\
\text { (no.) }\end{array}$ & $\begin{array}{c}\text { Apical } \\
\text { phylloclades } \\
\text { with new } \\
\text { phylloclades } \\
(\%)\end{array}$ & $\begin{array}{c}\text { New apical } \\
\text { phylloclades/ } \\
\text { plant } \\
\text { (no.) }\end{array}$ \\
\hline 0 (control) & $\cdots$ & 100 & 60 & 82 & 25.3 & 4 & 0.6 \\
\hline \multirow[t]{5}{*}{5} & -20 & 100 & 61 & 75 & 16.4 & 2 & 0.3 \\
\hline & -10 & 100 & 64 & 76 & 24.5 & 0 & 0 \\
\hline & 0 & 100 & 62 & 63 & 17.0 & 9 & 1.8 \\
\hline & 10 & 100 & 58 & 75 & 20.4 & 5 & 1.4 \\
\hline & 20 & 100 & 55 & 82 & 24.8 & 1 & 0.3 \\
\hline \multirow[t]{5}{*}{50} & -20 & 100 & 73 & 31 & 6.6 & 10 & 2.5 \\
\hline & -10 & 100 & 83 & 25 & 7.0 & 22 & 6.5 \\
\hline & 0 & $50^{x}$ & 85 & 6 & 1.5 & 22 & 7.0 \\
\hline & 10 & 100 & 56 & 42 & 11.1 & 5 & 1.0 \\
\hline & 20 & 100 & 56 & 68 & 19.4 & * & 0.6 \\
\hline \multirow[t]{4}{*}{500} & -20 & $13^{x}$ & 92 & 1 & 0.1 & 32 & 10.5 \\
\hline & -10 & $0^{x}$ & --- & 0 & 0 & 33 & 10.4 \\
\hline & 0 & $13^{x}$ & 77 & 1 & 0.3 & 22 & 5.6 \\
\hline & 10 & 100 & 58 & 42 & 7.9 & 4 & 0.6 \\
\hline . & 20 & 100 & 55 & 75 & 22.8 & 2 & 0.5 \\
\hline \multicolumn{8}{|l|}{ Contrasts } \\
\hline Control vs. $\mathrm{GA}_{3}$, day -20 & & & $* * *$ & $* * *$ & $* * *$ & $*$ & $*$ \\
\hline Control vs. $\mathrm{GA}_{3}$, day -10 & & & $* * *$ & $* * *$ & $* * *$ & $* *$ & $* * *$ \\
\hline Control vs. $\mathrm{GA}_{3}$, day 0 & & & $* * *$ & $* * *$ & $* * *$ & $* *$ & $* *$ \\
\hline Control vs. $\mathrm{GA}_{3}$, day 10 & & & NS & $* * *$ & $* * *$ & NS & NS \\
\hline Control vs. $\mathrm{GA}_{3}$, day 20 & & & $*$ & NS & NS & NS & NS \\
\hline Control vs. $5 \mathrm{mg} \cdot \mathrm{liter}^{-1}$ & & & NS & NS & NS & NS & NS \\
\hline Control vs. $50 \mathrm{mg} \cdot$ liter $^{-1}$ & & & $* * *$ & $* * *$ & $* * *$ & NS & $* * *$ \\
\hline Control vs. $500 \mathrm{mg} \cdot$ liter $^{-1}$ & & . & $\mathbf{w}$ & $* * *$ & $* * *$ & $* *$ & $* * *$ \\
\hline $50 \mathrm{mg} \cdot$ liter $^{-1}$ vs. $500 \mathrm{mg} \cdot$ liter $^{-1}$ & & & w & $* * *$ & $* * *$ & * & $*$ \\
\hline $5 \mathrm{mg} \cdot$ liter $^{-1}$, date linear & & & $* * *$ & NS & NS & NS & NS \\
\hline $5 \mathrm{mg} \cdot$ liter $^{-1}$, date quadratic & & & * & $*$ & NS & NS & NS \\
\hline $50 \mathrm{mg} \cdot$ liter $^{-1}$, date linear & & & $* * *$ & $* * *$ & $* * *$ & $*$ & $* *$ \\
\hline $50 \mathrm{mg} \cdot$ liter $^{-1}$, date quadratic & & & $* * *$ & $* * *$ & $* * *$ & $* *$ & $* *$ \\
\hline $500 \mathrm{mg} \cdot \mathrm{liter}^{-1}$, date linear & & & w & $* * *$ & $* * *$ & $* * *$ & $* * *$ \\
\hline $500 \mathrm{mg} \cdot$ liter $^{-1}$, date quadratic & & & $w$ & $* * *$ & $* * *$ & NS & NS \\
\hline
\end{tabular}

${ }^{\mathrm{z}}$ Days relative to before $(-)$ or after the start of long days.

yDays to flowering from start of long days (31 Jan. 1989) for all treatments.

${ }^{x}$ Treatment significantly different from control by chi-square test, $P \leq 0.05$; chi-square $=3.841$ for $1 \mathrm{df}$.

${ }^{\text {w }}$ Contrast not estimable due to missing values or treatments.

Ns, ${ }^{* * * * * * *}$ Nonsignificant or significant at $0.05 \geq \alpha>0.01,0.01 \geq \alpha>0.001$, or $\alpha \leq 0.001$, respectively, according to F test of contrast between treatments.

clades flowering and number of flower buds per plant were not affected. $\mathrm{GA}_{3}$ at $5 \mathrm{mg} \cdot$ liter $^{-1}$ generally did not affect vegetative growth or flowering, regardless of application time, but was as effective as 50 or $500 \mathrm{mg} \cdot \operatorname{liter}^{-1}$ in accelerating flowering when applied 20 days after the start of LDs.

$\mathrm{GA}_{3}$-treated plants generally produced more new phylloclades than the controls (Table 3 ). There was a highly significant negative correlation between the number of flower buds per plant and new apical phylloclades per plant $(r=-0.83), \mathrm{P}<0.001$ under $\mathrm{H}_{\mathrm{o}}$ : rho $=0(\mathrm{n}=14)]$. There was also a highly significant negative correlation between the percentage of apical phylloclades flowering and the percentage of apical phylloclades with new phylloclades $(r=-0.91), \boldsymbol{P}<0.001$ under $\mathrm{H}_{\mathrm{o}}:$ rho $\left.=0(\mathrm{n}=14)\right]$. The number of new phylloclades depended on $\mathrm{GA}_{3}$ concentration and application time. Applying $\mathrm{GA}_{3}$ from 20 days before to the start of LDs resulted in a higher percentage of apical phylloclades with new phylloclades and more new apical phylloclades per plant compared with the controls (Table 3 ). There were no differences between controls and plants treated with $\mathrm{GA}_{3}$ at $5 \mathrm{mg} \cdot \operatorname{liter}^{-1}$ in the percentage of apical phylloclades with new phylloclades or the number of new apical phylloclades per plant. However, increasing $\mathrm{GA}_{3}$ from 50 to $500 \mathrm{mg} \cdot \mathrm{liter}^{-1}$ resulted in a higher percentage of apical phylloclades with new phylloclades and more new apical phylloclades per plant.

The morphology of flowers and phylloclades was altered by $\mathrm{GA}_{3}$. Relative to the controls, new phylloclades and flowers on plants treated with $\mathrm{GA}_{3}$ at 50 or $500 \mathrm{mg} \cdot$ liter $^{-1}$ were thinner and elongated (data not presented). $\mathrm{GA}_{3}$ at $5 \mathrm{mg} \cdot \mathrm{liter}^{-1}$ did not affect the morphology of new phylloclades, but some flowers were elongated slightly when $\mathrm{GA}_{3}$ at $5 \mathrm{mg} \cdot \mathrm{liter}^{-1}$ was applied 20 days after starting LDs.

Flowering responses of intact plants depended on $\mathrm{GA}_{3}$ concentration, application time, and number of applications. A single $\mathrm{GA}_{3}$ application delayed flowering and reduced the percentage of apical phylloclades flowering and number of flower buds per plant when applied to plants before the formation of floral primordia, 
i.e., from 20 days before to the start of LDs, but hastened flowering and did not affect the percentage of apical phylloclades flowering or number of flower buds per plant when applied to plants during floral bud development, i.e., 20 days after starting LDs (Table 3). Increasing the concentration always resulted in longer flowering delays and fewer flowers when $\mathrm{GA}_{3}$ was applied at or before starting LDs. In addition, multiple $\mathrm{GA}_{3}$ applications were more inhibitory than single applications and resulted in fewer flowers and longer flowering delays (Table 2). Similar results were obtained with the SDP S. truncata (Fujihara, 1959; Halevy and Rudich, 1968; Ho et al., 1985; Runger, 1984). Rhipsalidopsis gaertneri and $S$. truncata are remarkably similar in their responses to $\mathrm{GA}_{3}$, even though $R$. gaertneri is a SLDP at 18 to $22 \mathrm{C}$ (Boyle et al., 1988; Boyle, 1991) whereas S. truncata is a SDP at 15 to 21C (Runger and Poole, 1985). The results of the current experiments and those with $S$. truncata demonstrate that $\mathrm{GA}_{3}$ may inhibit or promote flowering, depending on the stage of plant development when applied.

Experiment 3. Contaminated cultures (13 in total) were discarded before data collection. Statistical analysis was performed on data collected from 87 uncontaminated cultures.

For number of flower buds per explant and $2^{\circ}$ phylloclades per explant, there were no significant differences between the two experiments (21 Feb. and 12 Mar. 1990) nor was there a significant experiment $\times \mathrm{GA}_{3}$ interaction (Table 4). Both variables, however, were significantly affected by $\mathrm{GA}_{3}$ concentration. The number of flower buds decreased linearly as $\mathrm{GA}_{3}$ concentration increased, and the percentage of explants with flower buds was significantly lower among explants cultured in $\mathrm{GA}_{3}$-amended medium compared to those in $\mathrm{GA}_{3}$-free medium (Table 5). The percentage of explants with $2^{\circ}$ phylloclades and the percentage of explants with spine growth were significantly higher among those cultured in $\mathrm{GA}_{3}$-amended medium than in those in $\mathrm{GA}_{3}$-free medium. $\mathrm{GA}_{3}$ increased the number of $2^{\circ}$ phylloclades compared to the controls, but the response to $\mathrm{GA}_{3}$ concentration was nonlinear. The number of $2^{\circ}$ phylloclades increased as $\mathrm{GA}_{3}$ concentration increased from 0 to $1 \mathrm{mg} \cdot$ liter $^{-1}$, and then decreased at concentrations $>1 \mathrm{mg} \cdot \mathrm{liter}^{-1}$. The correlation between numbers of flower buds per explant and $2^{\circ}$ phylloclades per explant was negative but not significant $(r=-$ $0.71, P>0.05$ under $\mathrm{H}_{0}$ : rho $=0(\mathrm{n}=5)$ ]. Lack of significance may have been due to the inhibition of flower and phylloclade formation when explants were cultured on medium containing $\mathrm{GA}_{3}$ at $100 \mathrm{mg} \cdot \operatorname{liter}^{-1}$ (Table 5).

Whole plants and cultured phylloclades exhibited similar reactions to $\mathrm{GA}_{3}$, but cultured phylloclades were more responsive to $\mathrm{GA}_{3}$ than intact plants (Tables 2, 3, and 5). GA 3 at $5 \mathrm{mg} \cdot \mathrm{liter}^{-1}$ generally did not affect the vegetative or reproductive growth of intact plants (Table 3), whereas $\mathrm{GA}_{3}$ at $0.1 \mathrm{mg} \cdot \mathrm{liter}^{-1}$ inhibited flowering and promoted vegetative growth in cultured phylloclades (Table 5). Mauseth and Halperin (1975) also reported that $\mathrm{GA}_{3}$ at concentrations as low as $0.01 \mathrm{mg} \cdot$ liter $^{-1}$ elicited responses in quiescent buds of $O$. polyacantha that were cultured in vitro. In Expt. 2, the maximum number of new phylloclades was obtained when plants were treated with $\mathrm{GA}_{3}$ at $500 \mathrm{mg} \cdot \operatorname{liter}^{-1}$ (Table 3); in

Table 4. Analysis of variance for flower bud and phylloclade development for cultured phylloclades of 'Crimson Giant' Easter cactus (Expt. 3).

\begin{tabular}{|c|c|c|c|}
\hline \multirow[b]{2}{*}{ Source of variation } & \multirow[b]{2}{*}{ df } & \multicolumn{2}{|c|}{ Mean squares } \\
\hline & & $\begin{array}{c}\text { Flower buds/ } \\
\text { explant } \\
\text { (no.) }\end{array}$ & $\begin{array}{c}2^{\circ} \text { Phylloclades/ } \\
\text { explant } \\
\text { (no.) }\end{array}$ \\
\hline$\overline{\text { Experiment }(\mathrm{E})^{z}}$ & 1 & 0.0132 & 0.0055 \\
\hline Replications within $\mathrm{E}$ & 18 & 0.0096 & 0.0297 \\
\hline $\mathrm{GA}_{3}$ concentration $\left(\mathrm{GA}_{3}\right)$ & 4 & $0.5584^{* * *}$ & $0.2900^{* * *}$ \\
\hline $\mathrm{E} \times \mathrm{GA}_{3}$ & 4 & 0.0112 & 0.0142 \\
\hline Pooled Error & 59 & 0.0181 & 0.0421 \\
\hline
\end{tabular}

${ }^{\mathrm{z}} \mathrm{F}$ test performed using replications within $\mathrm{E}$ as the error term.

${ }^{* * *}$ Significant at $P \leq 0.001$.

Table 5. Influence of $\mathrm{GA}_{3}$ concentration on flowering and vegetative growth of cultured phylloclades of 'Crimson Giant' Easter cactus (Expt. 3).

\begin{tabular}{|c|c|c|c|c|c|}
\hline $\begin{array}{l}\mathrm{GA}_{3} \\
\text { concn } \\
\left(\mathrm{mg} \cdot \mathrm{liter}^{-1}\right)\end{array}$ & $\begin{array}{c}\text { Explants } \\
\text { with } \\
\text { flower } \\
\text { buds } \\
(\%)\end{array}$ & $\begin{array}{c}\text { Flower buds/ } \\
\text { explant } \\
\text { (no.) }\end{array}$ & $\begin{array}{c}\text { Explants } \\
\text { with } 2^{\circ} \\
\text { phylloclades } \\
(\%)\end{array}$ & $\begin{array}{c}2^{\circ} \\
\text { Phylloclades/ } \\
\text { explant } \\
\text { (no.) }\end{array}$ & $\begin{array}{l}\text { Explants } \\
\text { with } \\
\text { spine } \\
\text { growth } \\
(\%)\end{array}$ \\
\hline 0 (control) & 100 & 1.9 & $\overline{0}$ & 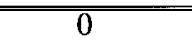 & $\overline{0}$ \\
\hline 0.1 & $47^{2}$ & 0.5 & $33^{z}$ & 0.6 & $60^{2}$ \\
\hline 1 . & $11^{z}$ & 0.2 & $68^{\mathrm{z}}$ & 1.4 & $100^{z}$ \\
\hline 10 & $22^{z}$ & 0.2 & $61^{2}$ & 1.1 & $100^{2}$ \\
\hline 100 & $12^{2}$ & 0.1 & $29^{z}$ & 0.4 & $100^{2}$ \\
\hline \multicolumn{6}{|l|}{ Contrasts } \\
\hline Control vs. $\mathrm{GA}_{3}$ & & $* * *$ & & $* * *$ & \\
\hline $\mathrm{GA}_{3}$ lincar & & $* * *$ & & NS & \\
\hline $\mathrm{GA}_{3}$ quadratic & & NS & & NS & \\
\hline
\end{tabular}

${ }^{\mathrm{z}}$ Treatment significantly different from control by chi-square test, $P \leq 0.05$; chi-square $=3.841$ for $1 \mathrm{df}$. Ns,***,*** Nonsignificant or significant at $0.05 \geq \alpha>0.01,0.01 \geq \alpha>0.001$, or $\alpha \leq 0.001$, respectively, according to $F$ test of contrast between treatments. 
Expt. 3, the number of $2^{\circ}$ phylloclades was maximal when explants were cultured on media containing $\mathrm{GA}_{3}$ at $1 \mathrm{mg} \cdot$ liter $^{-1}$, and concentrations $>1 \mathrm{mg} \cdot$ liter $^{-1}$ inhibited phylloclade formation (Table 5). Differences between cultured phylloclades and intact plants in responsiveness to $\mathrm{GA}_{3}$ may have been due to greater hormone uptake in the former, possibly due to direct contact between the $\mathrm{GA}_{3}$-containing medium and the wounded surface of the explant.

In Expt. 3, old spines were shorter (due to trimming) and paler (due to bleaching) than new spines; as a consequence, spine growth on the composite areole was evaluated readily. Spine growth increased when phylloclades were cultured in medium containing $\mathrm{GA}_{3}$ at $>0.01 \mathrm{mg} \cdot \operatorname{liter}^{-1}$ (Table 5). GA also increased the growth of spines in Chamaecereus silvestri (Speg.) Britt. \& Rose (Sanderson et al., 1986), Mammillaria elongata DC. (Sanderson et al., 1986), and O. microdasys (Lehm.) Pfeiff. (White et al., 1978). Exogenously applied $\mathrm{GA}_{3}$ may have induced spine growth in 'Crimson Giant' by triggering the initiation of new spines, as reported by Mauseth and Halperin (1975) and Mauseth (1977) for $O$. polyacantha. Cactus spines are presumed to be evolutionarily derived from leaves (Boke, 1944), and since directly applying $\mathrm{GA}_{3}$ can stimulate leaf growth (Aloni and Pressman, 1980; Gray, 1957), it is feasible that $\mathrm{GA}_{3}$ may also promote spine growth by increasing cell division or elongation or both within existing spine primordia. Additional research is needed to discern the mechanisms responsible for $\mathrm{GA}_{3}$-induced spine growth in 'Crimson Giant'.

Intact plants and cultured phylloclades generally produced more new phylloclades as $\mathrm{GA}_{3}$ concentration increased, i.e., the opposite trend observed for number of flower buds (Tables 3 and 5). This inverse relationship between vegetative growth and flowering is demonstrated by the highly significant negative correlation between the numbers of flower buds per plant and new apical phylloclades per plant $(r=-0.83)$. Phylloclade growth of 'Crimson Giant' may have been directly and indirectly affected by $\mathrm{GA}_{3}$. Direct stimulation of stem growth via increased cell division and cell elongation has been demonstrated in several species after GA was applied (Sachs, 196 1), and $\mathrm{GA}_{3}$ would be expected to have similar effects on phylloclade growth. Also, $\mathrm{GA}_{3}$ may have indirectly affected phylloclade growth by inhibiting flowering. Profuse flowering and a near absence of new phylloclades was the normal pattern of development, as exhibited by the controls (Tables 2 and 3 ). The flowering process may repress vegetative growth, and $\mathrm{GA}_{3}$ may have reversed the repression of vegetative growth by inhibiting flowering, thus allowing phylloclades to form. $\mathrm{GA}_{3}$ also promoted shoot growth in intact plants of $\mathrm{C}$. silvestri (Sanderson et al., 1986), M. elongata (Sanderson et al., 1986), and S. truncata (Yonemura, 1979).

Horticultural significance. Applying $\mathrm{GA}_{3}$ from 20 days before to 10 days after the start of LDs was either ineffective or inhibitory to flowering and, thus, would have no horticultural value for producing Easter cactus. However, a single application of $\mathrm{GA}_{3}$ at $5 \mathrm{mg} \cdot$ liter $^{-1}$ accelerated flowering by 5 days when applied to plants with 1-to 2-mm-long flower buds. Accelerating flowering reduces the cropping period and may aid in Easter cactus crop scheduling. $\mathrm{GA}_{3}$ at concentrations $>5 \mathrm{mg} \cdot$ liter $^{-1}$ will also accelerate flowering, but may decrease plant quality and marketability due to deleterious effects on phylloclade and flower morphology.

\section{Literature Cited}

Aloni, B. and E. Pressman. 1980. Interaction with salinity of $\mathrm{GA}_{3}$ induced leaf elongation, petiole pithiness and bolting of celery. Scientia Hort. 13:135-142.

Barthlott, W. 1987. New names in Rhipsalidinae(Cactaeae).Bradley a 5:97-100.
Boke, N.H. 1944. Histogenesis of the leaf and areole inOpuntia cylindrica. Amer. J. Bot. $31: 299-316$.

Boyle, T.H. 1991. Temperature and photoperiodic regulation of flowering in 'Crimson Giant' Easter cactus. J. Amer. Soc. Hort. Sci. 116:618-622.

Boyle, T.H. 1992. Modification of plant architecture in 'Crimson Giant' Easter cactus with benzyladenine. J. Amer. Soc. Hort. Sci. 117:584-589.

Boyle, T. H., D.J. Jacques, and D.P. Stimart. 1988. Influence of photopenod and growth regulators on flowering of Rhipsalidopsis gaertneri. J. Amer. Soc. Hort. Sci. 113:75-78.

Bünsow, R. and R. Harder. 1956. Blütenbilding von Bryophyllum durch Gibberellin. Naturwissenschaften 43:479-480.

Chouard, P. 1960. Vernalization and its relations to dormancy. Annu. Rev. Plant Physiol. 11: 191-238.

Fujihara, K. 1959. Effect of gibberellin on the flowering of Christmas cactus. I. Effect of gibberellin given at various times prior to or after the start of short days. J. Hort. Assn. Jpn. 28:200-208.

Gibson, A.C. and P.S. Nobel. 1986. The cactus primer. Harvard Univ., Cambridge, Mass.

Gomez, K.A. and A.A. Gomez. 1984. Statistical procedures for agricultural research. 2nd ed. Wiley, New York. p. 187-240, 272-315.

Gray, R.A. 1957. Alteration of leaf size and shape and other changes caused by gibberellins in plants. Amer. J. Bot. 44:674-682.

Greulach, V.A. and J.G. Haesloop. 1958. Influence of gibberellin on Xanthium flowering as related to number of photoinductive cycles. Science 127:646-647.

Halevy, A.H. and Y. Rudich. 1968. Effect of short-day and gibberellin on flowering in zygocactus. Symp. Plant Production Containers, Intl. Soc. Hort. Sci., Copenhagen, Denmark.

Ho, Y. S., K.C. Sanderson, and J.C. Williams. 1985. Effect of chemicals and photoperiod on the growth and flowering of Thanksgiving cactus. J. Amer. Soc. Hort. Sci. 110:658-662.

Kaukovirta, E. 1979. The effect of ethephon and chlormequat on flowering in Rhipsalidopsis gaertneri and the Zygocactus hybrid, "Weihnachtsfreude". Acta Hort. 91:419-424.

Ketellapper, H.J., and A. Barbaro. 1966. The role of photoperiod, vernalization and gibberellic acid in floral induction in Coreopsis grandiflora Nutt. Phyton (Buenos Aires) 23:33-41.

Lang, A. and E. Reinhard. 1961. Gibberellins and flower formation. Adv. Chem. 28:71-79.

Liberty Hyde Bailey Hortorium. 1976. Hortus third: A concise dictionary of plants cultivated in the United States and Canada. MacMillan, New York. p. 947-948.

List, R.J. 1951. Smithsonian meteorological tables. 6th ed. Smithsonian Inst., Washington, D.C. p. 506-512.

Mauseth, J.D. 1977. Cytokinin- and gibberellin acid-induced effects on the determination and morphogenesis of leaf primordia in Opuntia polyacanitha (Cactaceae). Amer. J. Bot. 64:337-346.

Mauseth, J.D. and W. Halperin. 1975. Hormonal control of organogenesis in Opuntia polyacantha (Cactaceae). Amer. J. Bet. 62:869-877.

Murashige, T. and F. Skoog. 1962. A revised medium for rapid growth and bioassays with tobacco tissue cultures. Physiol. Plantarum 15:473-497.

Nanda, K. K., T.A. Anaradha, and K. Lal. 1967. Floral induction by gibberellic acid in Impatiens balsamina $\mathrm{L}$., a qualitative short-day plant. Planta 76:367-370.

Penner, J. 1960. Über den Einfluß von Gibberellin auf die photoperiodisch bedingten Blühvorgange bei Bryophyllum. Planta 55:542-572.

Rünger, W. 1984. Einfluß von Wachstumregulatoren im frühen und späten Stadium der Knospenentwicklung bei Schlumbergera. Gartenbauwissenschaft 49: 100-103.

Rünger, W. and R.T. Poole. 1985. Schlumbergera, p. 277-282. In: A.H. Halevy (cd.). Handbook of flowering. vol. 4. CRC Press, BocaRaton, Fla. Sachs, R.M. 1961. Gibberellin, auxin, and growth retardant effects upon cell division and shoot histogenesis. Adv. Chem. Ser. 28:49-58.

Salisbury, F.B. andC.W. Ross. 1978. Plant physiology. 2nd ed. Wadsworth Publishing, Belmont, Calif. p. 377-430.

Sanderson, K. C., Y.S. Ho, W.C. Martin, and R.B. Reed. 1986. Effect of photoperiod and growth regulators on growth of three Cactaceae. HortScience 21:138 1-1382.

SAS Institute. 1985. SAS/STAT guide for personal computers. version 6. 
SAS Institute, Cary, N.C.

Stuart, N.W. and H.M. Cathey. 1962. Control of growth and flowering of Chrysanthemum morifolium and Hydrangea microphylla by gibberellin, p. 391-399. In: J. Garnaud (cd.). Advances in horticultural science and their applications. vol. 2. Pergamon, New York.

van Bragt, J. and R.L.M. Pierik. 1971. The effect of autoclaving on the gibberellin activity of aqueous solutions containing gibberellin $\mathrm{A}_{3}, \mathrm{p}$. 133-137. In: J. van Bragt, D.A.A. Mossel, R.L.M. Pierik, and H. Veldstra (eds.). Effects of sterilization on components in nutrient media. H. Veenman \& Zonen N. V., Wageningen, The Netherlands.
Vince-Prue, D. 1975. Photoperiodism in plants. McGraw-Hill, London. p. 217-224; 302-303.

Wellensiek, S.J. 1960. Stem elongation and flower initiation. Proc. Akad. v. Wetenschappen C 63: 159-166.

White, J. W., C. Allen, M. Easley, and P. Strock. 1978. Effects of growth regulants on Opuntia basilaris. HortScience 13:181-182.

Wittwer, S.H. and M.J. Bukovac. 1958. The effects of gibberellin on economic crops. Econ. Bot. 12:213-255.

Yonemura, K. 1979. Studies on the control of flowering in Christmas cactus. Spec. Bul. Aichi-Ken Agr. Res. Ctr., Nagakute, Aichi, Japan. p. 32-33. 